\title{
CORRESPONDENCE
}

Continued from $p .8$

This is not the ideal test of "survival of the fittest"; it does not compare fitness and survival within one population. Instead, it compares populations, of which the later is descended from survivors of the earlier (at both the individual and the species level). The populations are separated by some millions of generations; this interval is long enough for comparison of the populations with an objective standard to reveal an increase in fitness. Could this cumulative increase in fitness be produced by anything except "survival of the fittest"?

\section{D.G. STEPHENSON}

\section{Department of Geology,}

University of Keele, UK

Rudwick, M.J.S. Br. J. Phil. Sci. 15, 27-40 (1964)

Paul, C.R.C. in Patterns of Evolution (ed. Hallam, A.) 125-158 (Elsevier, Amsterdam, 1977).

\section{University staffing}

SIR - On behalf of my members I should like to make comment on the article, "Change wanted"' in Nature of 11 June (p.442).

I do not wish to proffer an opinion on the second interim report from the SwinnertonDyer committee but I do want to protest most strongly about your suggestion that a cutback in non-academic staff would be quicker and should be considered first.

First, the financial savings accrued from such cuts would be a drop in the ocean in comparison with the salaries saved from the academic staff. We as technicians are aware of departments with an academic staff establishment which in no way reflects the actual number of students taught. It is the topheavy nature of such departments that needs careful consideration.

Second, the last sentence in the article asks "But is not the university an institution whose chief purpose is academic?'”. In order to maintain that purpose the academics need the back-up services of trained technicians to provide an efficient lab class and assist with research projects. An academic with a heavy teaching load trying to do research at the same time would either have to cut back the amount of teaching or give up a substantial part of his research projects in order to replace the technical services now provided.

As regards cleaners and porters, they already work in rather grubby conditions and am sure that academic standards would not be improved if the academics had to clean their own rooms or provide an adequate supply of toilet paper in the lavatories.

In conclusion, we are aware that because of government cuts, savings must be found somewhere. But please do not point the finger at one group of staff. Far rather let each college put its own house in order and safeguard the jobs and careers of all its employees by looking at other areas of saving first.

The universities could also make a positive and voluble stand against the government cuts in an effort to maintain the opportunity of higher education for as many people as possible.

A.L. Price Thomas

Branch Chairman,

Association of Scientific, Technical and Managerial Staffs,

Westfield College Branch, London NW3, UK
Psychiatry on trial

SIR - Your ill-disguised dismissal of R.D. Laing (Nature 4 June, p.367) does little to clarify the many interconnected issues raised by the Sutcliffe case. Permit me to draw the following lessons from his trial:

(1) Escape into the protection of some illness, however well-defined or spurious, is no longer possible. Each of us needs to accept responsibility for our actions.

(2) The utter "normality" displayed by Sutcliffe during his trial now puts the onus on psychiatry to defend its labelling of unacceptable behaviour as "illness"': may I remind you that there are psychiatrists amongst those who collude in the incarceration of Soviet dissidents.

(3) That anyone, particularly psychiatrists, should be surprised when the "common and pervasive" sexual abuse of, and violence towards women takes such an extreme form, is but a sad reflection on our society. Where I beg to differ from you is in not ascribing this to "psychiatric illness" but rather to the inevitable consequence of a pervasive morality. The sooner we stop hiding behind the comfort of psychiatric illness the better we shall see our own responsibility as members of the society that has nurtured Sutcliffe.

K. Paulus

Clifton, Bristol, UK

\section{Search for truth}

SIR - Although not directly involved in the investigation of the origin of species, astronomers are, nevertheless, involved at the "sharp end" of research into origins as they seek to explore the Universe and as such I would like to comment on the leading article "How true is the theory of evolution?" (Nature 12 March, p.75).

Darwin's theory of evolution, like the theory of special creation, is just that, a theory, which is incapable of being proved as fact by scientists, and also incapable of being falsified. Both theories therefore, if given the label of scientific theories, fulfil Popper's second criterion. Second, in order to assemble and evaluate evidence for particular theories, scientists, hopefully, try to be as objective as they possibly can; if not, then their credibility may well be called into question. However, most people would find it impossible to be totally objective and impartial in weighing up evidence. Each of us has prejudices which we are incapable of putting out of our minds as we seek to assess observed facts, so their interpretation can never be fully objective.

This problem is particularly acute when the origin of the species is being investigated. The whole question of the existence of God and as a consequence our accountability to him as God, past conflicts between church leaders and scientists, dissatisfaction with the implications of evolution on the one hand and with the role of the Bible and the church on the other have all made the investigation of the origin of the species a good deal more subjective than other areas of scientific investigation.

Creationists will do themselves a great disservice by choosing to bury their heads in the sand as scientific investigation proceeds in the future but equally so will evolutionists if they draw up behind a barrier of indignation at the thought of Darwin's theory never achieving the status of fact.

Objectivity of investigation and interpretation is not only desirable but very necessary, for in the final analysis the truth will stand all investigations and still be the truth long after we are all laid to rest.

Howard READ

Department of Astronomy University of Manchester, UK

\section{American Creation}

SIR - The correspondence arising from the British Museum's cladistic activities has had one common aim - to avert the imminent threat of an upturn in creationism (Jukes, Nature 21 May p.186; editorial 28 May p.271). We are tempted to ask why evolutionism feels threatened by creationism, when the real controversy has not yet been stated openly. This does not lie in E. O. Wiley's question (Nature 30 April, p.730) "Does the phenomenon of evolution occur?", since the majority of creationists would not deny that evolution occurs, but in the question "Did the evolutionary mechanism provide the actual pathway from sterile Earth to living world?'

Any view of origins that does not invoke a supernatural Creator must conclude either that it did or that life arrived from space in some form, as proposed by Crick and Orgel,

Wickramasinghe and Hoyle, and others. Either view must be accepted by faith, either in the propositions themselves or in the ability of science to provide proof in the future. The atheist, whose metaphysical presuppositions do not allow him to countenance any form of divine activity, is more close-minded than many theists, who would happily accept either theory or the alternative, special creation.

To take a narrower view, any survey of Bible-believing Christians would reveal a wide spectrum of conclusions. These would range from those who believe that God has worked through essentially neo-Darwinian evolution, to those "creationists" who find current evidence for Darwinian evolution unconvincing and conclude that special creation is consistent not only with the scientific evidence but also with the whole of Scripture, the reliability of which can be verified experientially by the Christian.

It is often stated that many creationists take no account of the scientific arguments for evolution. Since the converse is also true, we will point to some of the issues we consider relevant. It is reasonable to point out that no plausible theoretical model exists which provides a mechanism for the spontaneous generation of nucleic acids as informational macromolecules specifying polypeptides which themselves mediate the replication and expression of that information. The experiments demonstrating the formation of a variety of organic molecules from presumptive prebiotic soups fall far short of providing a pathway for chemical evolution. Again, it is self-evident that the fossil record leaves much to be desired and few biologists recognise the dependence of the geological column on radiometric dating methods based on questionable assumptions about initial conditions. The whole history of evolutionary thought is littered with the debris of dubious assumptions and misinterpretations, especially in the area of fossil "hominids". To come up to date, protein and DNA sequence data, generally viewed as consistent with an 